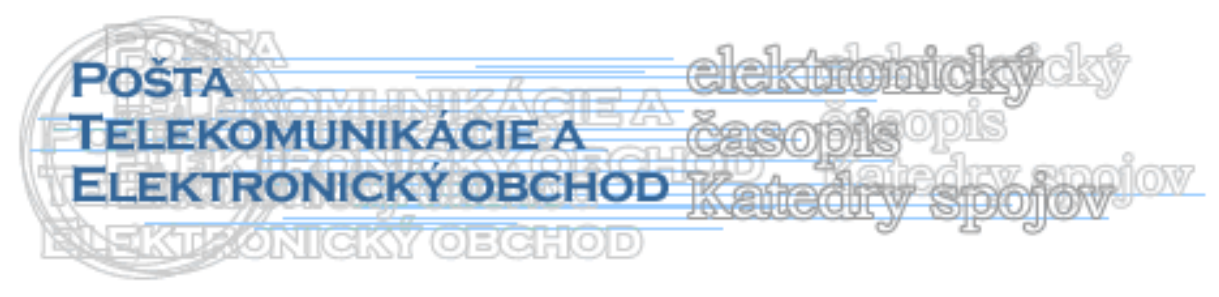

\title{
KONKURENCIESCHOPNOSŤ PODNIKOV V OBDOBÍ GLOBALIZÁCIE
}

\author{
Katarína Štofková*, Petra Kinzlová ${ }^{\dagger}$
}

Úvod

V súčasnosti, práve $\mathrm{v}$ dôsledku zmien vyplývajúcich z globalizácie, sa ako vel'mi aktuálna alternatívna stratégia pôsobenia na trhu pre malé a stredné podniky uvádza stratégia kooperácie. Jednou z foriem zvyšovania konkurencieschopnosti malých a stredných podnikov prostredníctvom kooperácie je vytváranie klastrov. Mnohé podniky individuálne nie sú schopné využit' výhody, ktoré ponúka globalizácia svetových trhov. Globalizácia vyžaduje inovatívne vysokoflexibilné riešenia, ktoré individuálne malé a stredné podniky nie sú schopné zabezpečovat'. Práve prostredníctvom kooperácie v rámci klastra je možné mnoho z týchto problémov prekonat'.

\section{Súčasný stav v problematike}

V „Konkurenčnej výhode národov“ (The Competitive Advantage of Nations) bola vyvinutá teória národných a lokálnych schopností konkurencie v globálnom ekonomickom kontexte. V rámci tejto teórie sa dostávajú podnikové klastre do výhodných postavení. Pri klastri sa jedná o geografickú koncentráciu podnikov, špecializovaných dodávatel'ov, poskytovatel'ov služieb, podnikov v príbuzných odvetviach a prepojených zariadeniach (napr. univerzity, inštitúty a hospodárske zväzy), ktoré sú na určitej úrovni navzájom poprepájané a súčasne si konkurujú a kooperujú [4].

Hoci pojem klaster bol preskúmaný v literatúre z takmer všetkých uhlov pohl'adu, nemožno tento pojem pozorovat' nezávisle od rozsiahlej teórie konkurencie a v globálnej ekonomike od vplyvu miesta. Skutočnost', že klaster prevláda oproti izolovanému podniku alebo odvetviu, objasňuje existenciu konkurencie a význam miesta pre výhody konkurencie. Aj ked' tradičné dôvody tvorby klastrov stratili na význame kvôli globalizácii, prevzal klaster novú úlohu rastúceho významu v porovnaní ku komplexnej, dynamickej a na vedomostiach závislej ekonomike.

Koncept klastrov tvorí nový obraz národných, regionálnych a lokálnych konfigurácií a zdôrazňuje, ktoré nové úlohy prináležia podniku, vláde a iným inštitúciám, ktoré sa snažia o konkurencieschopnost'. Existencia klastrov poukazuje na to, že výhody konkurencie nie sú bezpodmienečne umiestnené $\mathrm{v}$ podniku alebo $\mathrm{v}$ jeho odvetví.

\footnotetext{
* Ing. Katarína Štofková, PhD., Žilinská univerzita v Žiline, Fakulta PEDaS, Univerzitná 1, 01026 Žilina tel.: +421-041-5133139, e-mail: katarina.stofkova@fpedas.uniza.sk

† Ing.Petra Kinzlová, Žilinská univerzita v Žiline, Fakulta PEDaS, Univerzitná 1, 01026 Žilina tel.: +421-041-5133145, e-mail: petra.kinzlova@fpedas.uniza.sk
} 
Centrálny význam klastrov predstavuje manažment nových úloh, ktoré boli doteraz identifikované len v minimálnej miere. Podniky majú vel'ký záujem o vývoj ekonomického prostredia, na ktorom pôsobia, a tento záujem smeruje aj do oblasti daní, nákladov na energie a mzdové náklady. Zdravie klastrov je dôležité pre zdravie podnikov. Podnik môže dokonca profitovat' z prítomnosti lokálnych konkurentov. Obchodné komory, záujmové skupiny a sociálne organizácie môžu mat' na tvorbe konkurencie vel'ký podiel.

Klaster rovnako vytvára politiku pre nové úlohy. Poznatkom je, že konkurenčná schopnost' musí byt' podporovaná prostredníctvom vhodných politických nástrojov na makroekonomickej úrovni. Tieto sa síce stále viac presadzujú, ale stále ich nie je dostatok. Dôležitejšie sú často mikroekonomické opatrenia. Prednostný ciel' politiky by mal byt' taký, aby odstraňoval prekážky pre rast a d'alší rozvoj klastrov, ktoré už existujú ale i pre tie, ktoré práve vznikajú. Klastre lákajú zahraničných investorov a prispievajú podstatnou mierou k zvýšeniu exportu. Predstavujú platformu pre nové formy dialógu medzi podnikom, vládnymi úradmi a inštitúciami (ako školy, univerzity a zásobovacie podniky).

Vedomosti o teórii klastrov sa po zverejnení „Konkurenčnej výhody národov“ d’alej rozšírili a rozširujú sa nad'alej. Kniha vyvolala na národnej a dokonca aj na regionálnej úrovni rastúci počet oficiálnych iniciatív k tvorbe klastrov.

\section{Čo predstavuje pojem klaster?}

Klaster je skupina podnikov, ktoré sú koncentrované na určitom mieste a ich aktivity sú navzájom pospájané na určitej úrovni. Tieto podniky sú pospájané prostredníctvom spoločných a navzájom doplňujúcich schopností. Geograficky sa môže klaster nachádzat' na území jedného mesta alebo krajiny, ale tiež môže zahŕňat' siet' susedných krajín. Klastre prijímajú v závislosti od svojej bohatosti a stupňa rozvinutosti rôzne formy, ale spravidla zahŕňajú výrobcov konečného tovaru alebo služieb, dodávatel'ov špecializovaných tovarov, komponentov, strojov a služieb, finančné inštitúcie ako podniky príbuzných odvetví.

Často patria ku klastru aj podniky z iných odvetví (teda odbytové cesty a odberatelia), výrobcovia komplementárnych tovarov, poskytovatelia špecializovanej infraštruktúry, inštitúcie ponúkajúce vzdelávanie, informácie, vývoj a technickú podporu (ako univerzity a vzdelávacie inštitúty). Aj štátne úrady, pokial' majú vplyv na klaster, je možné považovat' za čast' jeho celku. Klastre zahŕňajú viaceré obchodné komory, ktoré sa zaviazali pre podporu členstva v klastri [5].

Aby sa zistilo, ktoré časti patria klastru, je nutné začat' pri väčšom podniku alebo koncentrácii podnikov a sledovat' predchádzajúce a nasledujúce stupne podniku a zariadenia vo vertikálnom ret’azci. Ďalší krok spočíva v stanovení horizontálnej úrovne pre každé odvetvie, ktorého odbytové cesty sa navzájom obsluhujú, alebo ktoré vyrábajú komplementárne produkty. Ďalšie horizontálne odvetvové ret’azce sú poznačené prostredníctvom použitia podobných špecializovaných produkčných faktorov alebo technológií, alebo poukazujú na iné spojenia na strane vstupov. Potom čo sa zistí, ktoré odvetvia a podniky patria ku klastru, je potrebné zistit', ktoré inštitúcie zásobujú klaster špecializovanými poznatkami, technológiami, informáciami, kapitálom alebo infraštruktúrou a ktoré spoločné zariadenia sa starajú o členov klastra. V poslednom kroku sa zist'uje, ktoré štátne úrady majú značný vplyv na subjekty patriace do klastra.

$\mathrm{Na}$ obrázku č. 1 je uvedený schematický diagram talianskeho klastra obuvi a módy. Tento diagram síce nezachytáva všetky súčasti klastra, ale vysvetl'uje podstatné znaky tejto sústavy. Z obrázku je potom napríklad vidiet', ktoré retazce príbuzných odvetví tvoria taliansky klaster obuvi a módy. K tomu patria tie ret’azce, ktoré navzájom spájajú rôzne druhy kožených tovarov (prostredníctvom komplementárnych produktov, spoločných výrobných faktorov, podobných technológií), tie, ktoré spájajú rôzne kategórie obuvi (prostredníctvom 
navzájom sa prekrižujúcich odbytových ciest, podobných produkčných faktorov a technológií) a tie, ktoré spájajú rôzne druhy módneho tovaru (prostredníctvom komplementárnych produktov). Výnimočnú silu talianskeho klastra vidíme aj na početných spojeniach a synergiách medzi jednotlivými talianskymi podnikmi.

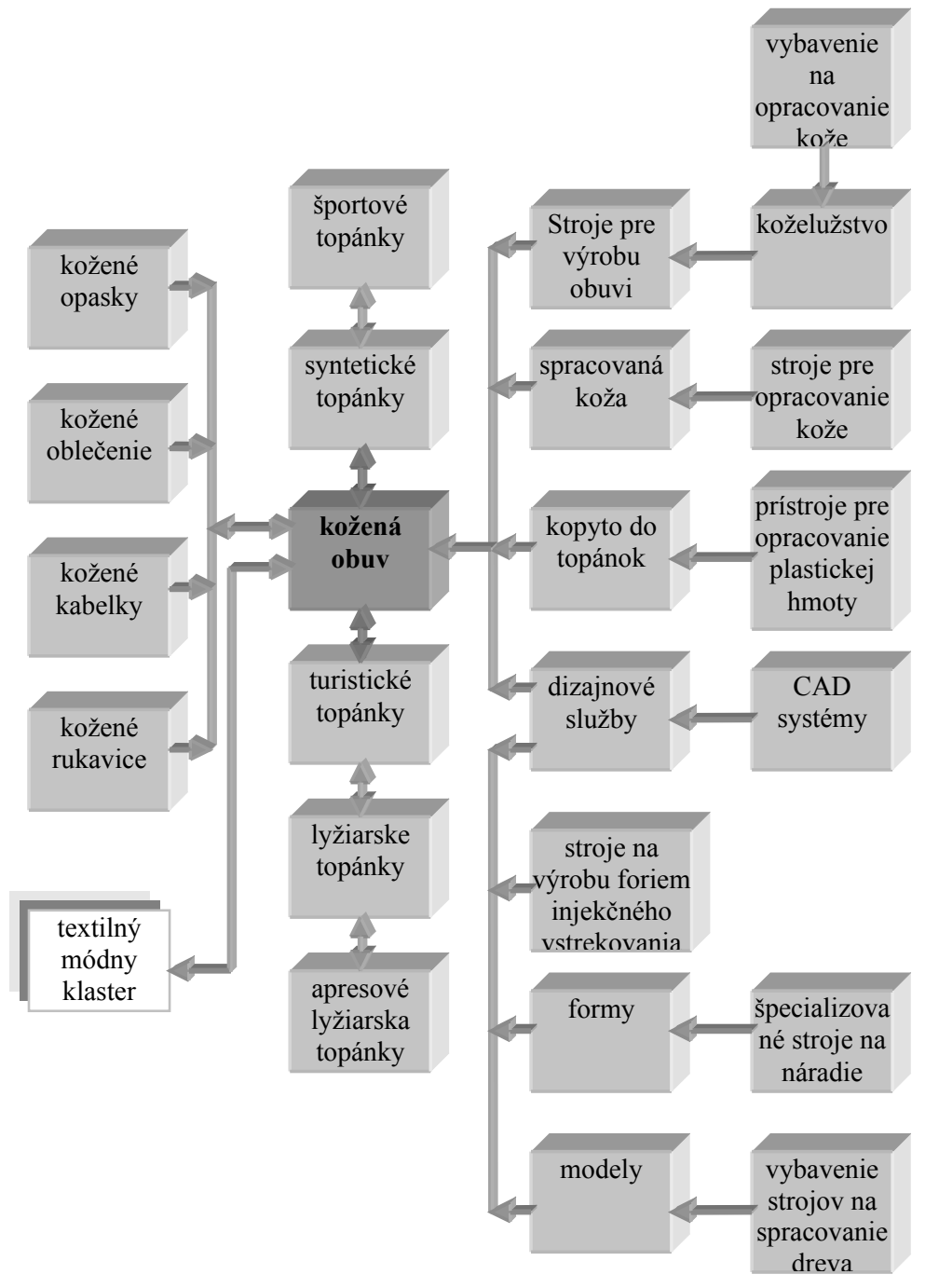

Obrázok č.1 : Taliansky klaster obuvi a módy [2]

Otázky, akým spôsobom sa majú určit' hranice klastra, závisia často len od menších odlišností. Jedná sa o kreatívne posúdenie, do akej miery sa musí opierat' o vedomosti najdôležitejších prepojení a doplnení o hraniciach odvetvia a inštitúcií. Sila týchto prospešných vedl'ajších účinkov a jej význam pre produktivitu a inováciu rozhodnú o tom, kadial' majú definitívne viest' hranice klastra. Napr. kancelársky nábytok, možnosti vybavenia štadiónov, vybavenie tried $\mathrm{v}$ školách, či automobily patria $\mathrm{k}$ ozrejmeniu pojmu klaster. Tieto produkty poukazujú na podstatné spoločné prvky vohlade na výrobné vlastnosti, výkonnostné vlastnosti, komponenty a technológie. Výrobcovia kovových dielov, výrobcovia plastov a tlačiarne sú tiež dodávatel'mi klastra. Tieto dodávatel'ské odvetvia môžu byt' pritom súčast'ou iného klastra, pretože zásobujú napríklad aj automobilový priemysel. Obzvlášt' pri kovových dieloch existuje skutočnost', že automobiloví dodávatelia jestvovali už vtedy, ako zásobovali automobilový klaster, čo prispelo k vývoju a vzniku klastra. Hranice klastra by 


\section{mali obsiahnut' všetky podniky, odvetvia a zariadenia, medzi ktorými vznikajú silné vertikálne, horizontálne alebo inštitucionálne spojenia.}

Klastre, ktoré zahrňujú vel'mi široké zoskupenia, napr. voblasti produkcie konzumných tovarov alebo špičkových technológií, je potrebné definovat'. V takomto prípade vznikajú len slabé prepojenia medzi členskými odvetviami. Ak naopak, označujeme jednotlivé odvetvia ako klastre, potom prehliadame podstatné odvetvie prekračujúce inštitucionálne prepojenia, ktoré trvale pôsobia na konkurenčnú situáciu.

Podstatné znaky klastrov [2]:

- klastre sa tvoria v rôznych odvetviach, v rôznych vel'kostiach a často dokonca aj v lokálnych oblastiach podnikania,

- nachádzajú sa vo vel'kých i malých ekonomických priestoroch, v mestách a na rôznych geografických úrovniach,

- existujú ako v priemyslových krajinách tak aj rozvojových krajinách, pričom sú však omnoho viac rozvinuté vo vysokorozvinutých ekonomických krajinách.

Klaster spočíva zvyčajne v kombinácii odvetví, ktoré zhotovujú konečné produkty, dodávajú stroje a materiál a prinášajú služby. Tieto odvetvia sa bežne zadel'ujú do rôznych kategórií. Často obsahujú tradičné ako aj špičkové odvetvia. To znamená, že je nutná taká evidencia a štatistika hospodárskych údajov ako aj definovanie ekonomiky, aby sa porozumelo ako fungujú klastre.

Niektoré časti klastra patria často do rôznych tradičných kategórií priemyslu a služieb. Často sa stáva, že dôležité klastre zostanú nerozoznané. Tak tomu bolo napríklad aj $\mathrm{v}$ americkom meste Massachusetts, v oblasti s viac ako 400 podnikmi, ktoré sa zaoberali medicínskymi prístrojmi a zamestnávali 39000 l'udí. Napriek tomu ostal tento klaster dlhý čas prakticky neviditel'ný, pretože bol schovaný vo viacerých vel'kých priemyselných kategóriách ako elektronické prístroje či produkty z plastu. Neskôr došlo k objaveniu tohto klastra, ktorý bol základom založenia spoločenstva podnikov MassMedic a prijatím produktívneho dialógu s vládou.

Klastre sa odlišujú v závislosti od vel'kosti, šírky pôsobenia a štádia vývoja. Niektoré klastre pozostávajú v prvom rade z malých a stredných podnikov (napr. taliansky obuvnícky klaster). Iné obsahujú vel'ké ako aj malé podniky (napr. nemecký chemický klaster). Niektoré klastre sa tvoria okolo univerzít, kým ostatné nemajú ešte žiadne vzt'ahy k výskumným inštitúciám. Tieto rozdiely $\mathrm{v}$ charakteristike klastrov odzrkadl'ujú rozdiely $\mathrm{v}$ ich štruktúre. V lepšie rozvinutých klastroch sa nachádzajú špecializovaní dodávatelia, väčší počet príbuzných odvetví a podporných zariadení.

Hranice klastra sa neustále posúvajú, pretože neustále vznikajú nové podniky a odvetvia, etablované ekonomické odvetvia zanikajú a inštitúcie menia svoje ciele. Nové odvetvia prinášajú technologický pokrok a vývoj trhu vytvára nové prepojenia alebo sa menia trhy, ktoré zásobujú. Tiež zmeny právnych rámcových podmienok prispievajú k posúvaniu hraníc.

Klastre je možné skúmat' na rôznych úrovniach, pričom sa tu vynárajú rôzne vlastnosti. V Kalifornii napríklad existuje vel'ký pol’nohospodársky klaster. Analýza tohto rozsiahleho klastra poskytuje podstatné pohl'ady do konkurenčnej situácie. Analýza na tejto úrovni podporuje objavovanie niektorých špecifických vlastností (napríklad prepojenia vedúce $\mathrm{k}$ turistickým klastrom).

\section{Záver}

Z vyššie uvedeného textu sa nám naskytne otázka, prečo by sa malo vychádzat' z klastrov pri analýze národného hospodárstva, miesto tradičného zoskupovania podnikov, odvetví alebo sektorov, ako je výroba alebo služby? Najdôležitejší dôvod spočíva v tom, že 
pri analýze klastrov to viac vyhovuje podstate konkurencie a zdrojom konkurenčných výhod. Väčšina členov klastra si navzájom priamo nekonkuruje, ale zásobujú rôzne odvetvové segmenty.

Pokial' považujeme nejakú skupinu podnikov a zariadení za klaster, potom sa otvára možnost' koordinácie a pôsobenia v oblastiach spoločných záujmov, bez ktorých by sa znížila intenzita rivality. Klaster tvorí fórum, na ktorom sa môže odohrávat' konštruktívny a eficientný dialóg medzi príbuznými podnikmi a ich dodávatel'mi, medzi úradmi a inými podstatnými inštitúciami.

Verejné a právne investície, ktoré slúžia k zlepšeniu podmienok pre klaster, prospievajú množstvu podnikov. Pokial' podniky majú len úzko definované sektory ako napríklad pri výrobe automobilov, potom majú často sklony obmedzovat' sa na diskusie o subvenciách a o daňových zvýhodneniach. Verejné investície produkujú menej vedlajšieho úžitku pre iné odvetvia a zmenšujú tak možnosti na trhu. Pretože väčšina účastníkov sú priamymi konkurentmi, vzniká reálne nebezpečenstvo, že rivalita stratí na intenzite. Pri takýchto podmienkach by mohli mat' podniky obavu o členstvo v klastri, pretože sa boja, aby nepomohli priamym konkurentom. Koncentrácia na jednom odvetví alebo úzko obmedzenom priestore vedie tiež k deformácii konkurencie.

\section{Literatúra}

[1] Čorejová, T.: K hodnoteniu regionálneho podnikatel'ského prostredia. Rozwoj euroregionu Beskidy 2, Bielsko Biala, 2003

[2] Porter, M. E.: Wettbewerb und Strategie. München 1999, ISBN 3-430-17561-5

[3] Skokan, K.: Konkurenceschopnost, inovace a klastry v regionálním rozvoji. Ostrava 2004, ISBN 80-7329-059-6

[4] Štofková, J. a kol.: Manažment podniku. Žilina: EDIS - vydavatel'stvo Žilinskej univerzity v Žiline, 2007, ISBN 978-8070-713-2

[5] Štofková, K.: Výskum siet'ových procesov v regionálnom podnikatel'skom prostredí. Dizertačná práca. Žilinská univerzita v Žiline, 2007

[6] Europen Commission, Enterprise Directorate General: Final Report of the Expert Group on Enterprise Clusters and Networks. Bruxelles 2003

[7] OECD Proceedings: Boosting Innovation The Cluster Approach, OECD 1999

Príspevok bol spracovaný v rámci riešenia projektu MVTS Pol'/SR/ŽU1/07 Moderné trendy strategického manažmentu a ich aplikácia v podniku ako faktor zvyšovania konkurencieschopnosti a projektu MVTS Nem/SR/ŽU/3/07 Aplikácia cyklu PDCA v službách ako faktor zvyšovania efektívnosti riadenia. 